\title{
The Lacking of the Quran's Recitation within Society: An Initial Review
}

Sarah Nur Dalilah Kipayatu Allah, Wan Khairul Aiman Wan Mokhtar, Syaima' Syatirah Jaafar, Abdullah Ibrahim, Wan Mohd Khairul Firdaus Wan Khairuldin, Mohd Mustaffami Imas, Mohd A' Tarahim Mohd Razali, Eusoff Amiruddin \& Ahmad Safwan Jamaludin

To Link this Article: http://dx.doi.org/10.6007/IJARBSS/v10-i12/8217

DOI:10.6007/IJARBSS/v10-i12/8217

Received: 02 October 2020, Revised: 06 November 2020, Accepted: 30 November 2020

Published Online: 14 December 2020

In-Text Citation: (Allah et al., 2020)

To Cite this Article:Allah, S. N. D. K., Mokhtar, W. K. A. W., Jaafar, S. S., Ibrahim, A., Khairuldin, W. M. K. F. W., Imas, M. M., Razali, M. A. T. M., Amiruddin, E., \& Jamaludin, A. S. (2020). The Lacking of the Quran's Recitation within Society: An Initial Review. International Journal of Academic Research in Business and Social Sciences, 10(12), 69-77.

\section{Copyright: (c) 2020 The Author(s)}

Published by Human Resource Management Academic Research Society (www.hrmars.com)

This article is published under the Creative Commons Attribution (CC BY 4.0) license. Anyone may reproduce, distribute, translate and create derivative works of this article (for both commercial and non-commercial purposes), subject to full attribution to the original publication and authors. The full terms of this license may be seen

at: http://creativecommons.org/licences/by/4.0/legalcode

Vol. 10, No. 12, 2020, Pg. 69 - 77 


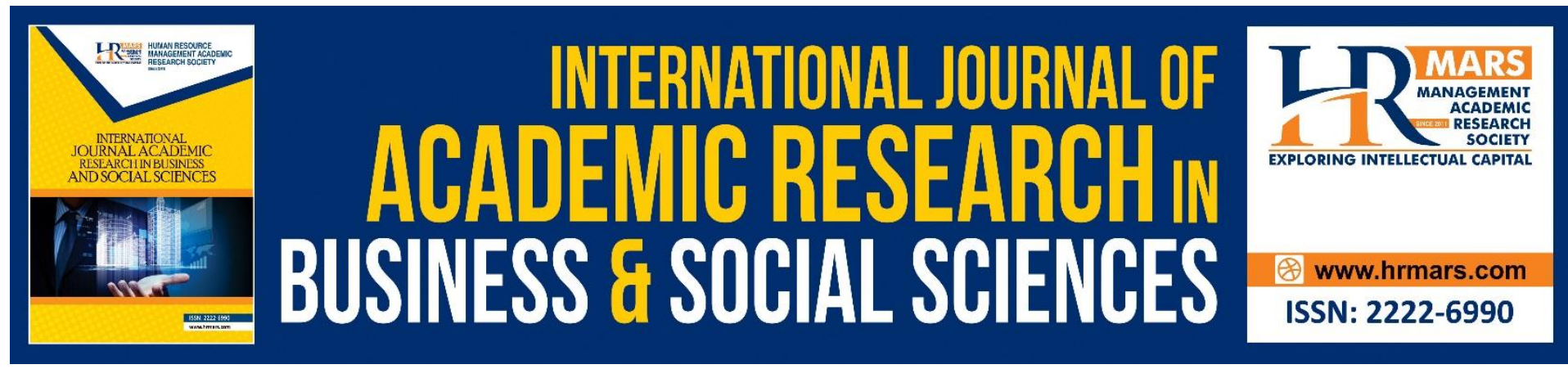

\title{
The Lacking of the Quran's Recitation within Society: An Initial Review
}

\author{
Sarah Nur Dalilah Kipayatu Allah, Wan Khairul Aiman Wan
} Mokhtar, Syaima' Syatirah Jaafar, Abdullah Ibrahim, Wan Mohd Khairul Firdaus Wan Khairuldin, Mohd Mustaffami Imas, Mohd A' Tarahim Mohd Razali, Eusoff Amiruddin \& Ahmad Safwan Jamaludin

Universiti Sultan Zainal Abidin (UniSZA), Kampus Gong Badak, 21300, Kuala Nerus, Terengganu, Malaysia

\begin{abstract}
Quran is the guide and the light for Muslims. As Muslims, we must hold a strong belief towards the Quran and it is obligatory to follow the path of light which is the Holy Quran. An issue comes to my attention, as a big number of people rarely read the Quran because of several reasons. Quran, as an eternal guide, should be taken seriously and should be practiced in all household to live in a happy and calm environment as well as to get the blessing of Allah. There are many questions to problems such as why do people nowadays only read the holy Quran once in a while? Why do people seem to not paying close attention to the benefits of reciting Quran? Why does the society of Muslims seem to lack the exposure to the importance of the Quran's recitation? This article is aiming to clear the way and answer the entire remaining question regarding the Quran's entity within the society by explaining further about the causes of lacking Quran's recitation, the effects of abducting Quran and possible ways to avoid the abandoned of Quran's recitation. Furthermore, the research is based on qualitative research. The sources come from the books in the library and online approved articles to create a faithful source that is free from plagiarism. By the end of this article, one may understand the importance of the Quran's recitation, the causes of lacking recitation of Quran, the obligatory of Quran recitation and the manners of Quran's recitation.
\end{abstract}

Keywords: Quran, Lack Recitation, Principle

\section{Introduction}

The highlighted issue in this article is that the decrease of Quran's recitation in today's world seems to not even bother the society to start shaping the practice. Based on the Oxford Islamic Studies Online (n.d.), the Quran is the main source for Muslims all around the world and the recitation of the Quran is standardized throughout the nation. The standardized way of reading the Quran shows that all of the Muslims is one and do not split apart. The holy Quran was transmitted to the prophet Muhammad (SAW) through so many stages and did not come as a whole at that time. Also, for Muslims, all of the confusion needs to bring back 
to what have the Quran stated whether it is something that needs to be done or something that needs to avoid. The strength of Muslims relies on the beliefs of Islam religion. The holy Quran also includes the guidance of political, economic and social, attitudes and the principle of faith. Moreover, the Quran consists of 114 Surahs and 6236 verses. The question is that why people nowadays choose not to recite the Quran regularly despite the various benefits of reciting the Holy Quran. Furthermore, the methods of research in this article are based on the official and reliable journal and books in order to come up with clean and truthful information. The good quality of the article may help society to further understanding and practising the deeds in the best way possible.

\section{Research Methodology}

This study uses a qualitative approach. Library data has been collected from journal articles, books, articles from websites as well as other library resources. The data collected were analyzed according to the analysis approach to the text. Next, the descriptions and discussions that have been made are formulated to conclude the discussion of this study (Mokhtar, 2017; Tzotzou, 2014).

\section{Findings and Research Discussion What Is the Quran?}

The Quran is a holy book in Islam religion and have over than 77,000 words altogether. It is delivered through Archangel Gabriel to Prophet Muhammad PBUH (Sharaf \& Atwell, n.d.). It has been delivered for over 23 years beginning in $610 \mathrm{CE}$ and made up of 114 chapters as well as the total of verses is 6,243 verses. According to Sharaf and Atwell (n.d.), the Quran is mushaf is widely-used by all Muslims all over the world. Many non-Arabic-speaking Muslims and non-Muslims have learned the classical-Arabic in order to understand the content of the Quran. The Quran is the best and the finest work in the Arabic literature and also hold a high status in society (Sharaf \& Atwell). Based on Sharaf and Atwell (n.d.), the Quran uses the classical Arabic language and considered as the highest text as well as frequently used as references in the linguistic scholarly works since the 7th century. Quran, as the main text in the Arabic literary, has been extensively studied and the scholarly volumes have been compiled elaborating the semantics, stylistic, linguistic and other aspects as well (Sharaf \& Atwell, n.d.).

The Quran is also widely-translated in almost all of the languages in the world, also they are various types of translations in just within one language and they can also be found in the electronic shapes in the web (Sharaf \& Atwell, n.d.). As the Quran is a notable source, the work of translation is being watched carefully to avoid any mistakes and wrong-doing of human works. The holy Quran also has other names such as Al-Syifa, Al-Huda, Az-Zikru, AlFurqan and Al-Mau'izhah. According to Salim and Abdullah (2014), there is not doubt even at the slightest towards the holy Quran and Sunnah and the explanations keep us to always remember the mightiness of Allah, the Creator. The main purpose of the Quran is that the Quran as a guide of revelation and not only for moral and law (Akhtar, 2008).

Keyword: What is the Quran?

\section{The Importance of Reciting the Quran}

The recitation of the Quran will not make us at a loss, but instead, it will give us so many benefits. One should be able to achieve a lot of amazing things just by reading the Quran. One of the great benefits that one will gain is that reciting the Quran can give you the peace that 
will make your life a great one. One study has been conducted by Fadhillah (2016), at the University of Yogyakarta, have shown that there is an effect on the student's emotional state by reciting the Quran. The birth of many social media platforms nowadays has positive and negative impacts themselves (Fadhillah, 2016). The users can develop many different kinds of emotion and also can lead them to an unstable emotional state. According to Hurlock (2002), health consistency just cannot simply change from one state to another state in instant (Fadhillah, 2016). Irma (2003) stated that emotion stabilization can only be achieved by the way they have been taught by their parents, the acceptance of oneself, the gut and the improvement of oneself (Fadhillah, 2016).

This concludes that the stability of emotional is crucial in order to keep on interacting with others (Fadhillah, 2016). Syakir (2014) once stated that research had been conducted before by Al-Qadhi in one of the clinics in Florida, United Stated to identify the benefits of the Quran recitation. Al-Qadhi found that the reading and listening of the Quran can lead to big psychological changes such as treating depression, grieving and even can avoid many diseases (Fadhillah, 2016). To strengthen the found, different doctors in the southern United States have also conducted the research and it has been proved that $97 \%$ of peace can be obtained from the holy Quran (Septian El Syakir, 2014 has been cited by Fadhillah, 2016). All in all, these shreds of evidence have been shown that by reading the Quran can bring peace to one's life. Another significant benefit of reading Quran is that Quran as the intercession to a person as it can help to ease the torment in the hereafter (Julianti, n.d.). Intercession is one of the ways to seek for forgiveness over the sins. There are several hadiths regarding the intercession form the Quran;

1. From Abu Umamah RA He said: I heard the Muhammad PBUH say, "Read the Quran, for it will come on the Day of Judgment (intercession) for its readers." (Narrated by Muslim)

2. From Usman bin 'Affan RA said: Muhammad PBUH. Said, "The best of men are those who study the Qur'an and teach it." (Narrated by Bukhari)

3. From Umar bin Al-Khattab RA. That Muhammad PBUH saw saying, "Verily, Allah exalted (some) dignity and degrades others for the sake of the Qur'an." (Narrated by Muslim)

To gain the intercession from the Quran, one must love the holy Quran as well as always recite the Quran (Julianti, n.d.)

Keywords: Emotional stability, Reading the Quran, Intercession

\section{The Factors That Lead to Lack of Quran's Recitation}

Every situation that occurs in one's life has the cause and its elaborations. Firstly, one of the most affected causes is the parents' attention to their children in order for them to gain a good Islamic education. Why do parents have a big responsibility for their children on their Islamic background knowledge? There are myriad of choices to choose from when deciding for the children's school according to the financial state of the parents which are religious schools and homeschooling (Badawi, 2006). According to Badawi (2006), the main option for the parents while choosing the best school is based on the social, moral and academic despite any other reasons such as the distance from home and the parents' financial state. Parents do not even care to double the work as long as their children are on the right track (Badawi, 2006). When it comes to religious schools, researchers have undergone a study regarding the 
Islamic school's position in North America and at the initial state; Islamic schools have not taken any place in the society. Surprisingly, the recent few years have shown a tremendous increase and more parents are choosing to school their children in a religious school (Badawi, 2006). Most of the parents responded to that research by stating that they want to put their children in an Islamic environment and that could be varied.

The intended Islamic environment is that the school can provide their children with a good education in morals, behaviors and practices (Badawi, 2006). Next, some parents also provide that the children will gain good religious education at the religious school and trusts that their children will live with it and they also stated that they can also teach their children at home by themselves regarding the Islamic teaches but they choose to let their children get the education at the religious school so that they will practice the teachings (Badawi, 2006). Other than that, according to Badawi (2006), parents decided to send their children to religious schools in order to preserve the Muslims identity within their children. The confession of a mother regarding the concerning reality that they need to face for an immigrant Muslims is that the different culture and tradition and she does not want their children to experience the same as them. The religious school can help children to preserve their identity and not get lost into the different contrast world (Badawi, 2006). That is why the parents' role is so important. Still, some parents do not provide all of the education that is needed to instill the ability and the awareness for their children to practice. For example, Islamic practices such as reciting the Quran.

Secondly, the reason of why the society nowadays rarely read Quran is the society nowadays does not understand the meaning of the verses in the Quran which will make them easily bored and abandoned the teachings in the Quran. According to Mohamed, Ismail and Saad (n.d.), some adults do not know the 'hijaiyyah' letters and even if they know it, they still cannot recite the Quran and not well-versed in the Quran's recitation. According to Daud (2005), this is caused by the less interest in the society since they are still in school. Also, to reinstate the values of learning Quran, a reformation must be done (Mohamed, Ismail and Saad, n.d.). In a developing era, various technologies have been introduced to the worlds to make things go thoroughly and smooth as well as making life more efficient.

\section{The Future of Quran}

The Quran is crucial to the entire human as it brings guidance and light as well as can bring one to the true path. This holy Quran needs to become the main source of any research. Currently, as the science and technology have become the most famous thing in the research, the mentality of Quran is being questioned and a number of the researches have not used the Quran as the main reference. According to Mohamad (1996), the study of Quran is obligatory as the Quran contains a lot of functions and bring a lot of benefits to the human and their needs as well as can solve all of the problems faced (Mohamed, Ismail \& Saad, n.d.). According to Az-Zuhaili (2005), the Quran education is complete and whole and the world life is only a journey and preparation to the hereafter life, and the Quran has the guidance of this world life as well as the afterlife (Mohamed, Ismail \& Saad, n.d.). Ahmad (2000) stated that the Quran teaches us that Allah is the main power and the one that we need to give ourselves in and believe in Him (Mohamed, Ismail \& Saad). Entire human is obliged to believe that the Holy Quran belongs to Allah and only Him, no one else including the Prophet Muhammad has the right on the Quran. 
The Quran outlines the morality and ethical behaviour (Sulaiman, 2014). The behaviour will be classified as good behaviour or bad behaviour and human needs to do a kindness or good behaviour and abandon the bad behaviour. There are four types of relationships that human needs to always bear in mind, which are the relationship of the individual and Allah, the relationship of the individual with himself, the relationship of individual with the fellow humans and lastly, the relationship of individual and all of Allah's creations such as animals and environment (Sulaiman, 2014). Sulaiman (2014) stated that the Quran teaches a ton of good values and moral values. For example, it teaches kindness, respect the parents, patience, honesty, justice and more. Those values have always been on top in human civilization have taken spot in any healthy human society.

\section{Optimizing the Quran Recitation Digitalized Quran}

According to Khan and Alginahi (2013), the Quran is the only religious books in the world that have not changed its content since the 14 th century. The traditional way of reciting the Quran, which is using mushaf is the most-used way of reading the Quran. Due to the technology era currently, the way people see things also change, as well as the way they recite Quran. A new, comfortable way needs to be added to the daily routine so that people will read more Quran. Islam has been known to the internet nowadays, more Muslims are using the internet for various purposes such as to communicate with others, educate themselves and also to spread the religion (Khan and Alginahi, 2013). Khan and Alginahi (2013) also stated that $30 \%$ of the people on earth which equal to over two billion users have used the internet. The Middle East recorded as the largest percentage of Internet usage, an increase of $2000 \%$ and 0.0125 of them is Muslims. This shows that the world view has changed due to the rapid development.

\section{The Obligatory of Reading Quran}

Reading the Quran is a must to the entire human. As Allah said in Surah Al-Alaq, verse 1:

"Recite in the name of your lord who created."

Another evidence of the importance of reciting Quran is:

"The best of you are the one that learns and teaches Quran to others." (Narrated by alBukhari)

According to Fauzan (2015), reading the Quran is considered as ibadah for Muslims and reciting the Quran will earn us rewards.

\section{Manner While Reciting Quran}

Reading the sacred Quran certainly needs to have certain manners in order for the human to have more respect for the Kalamullah. Despite the tajweed rules that we need to fulfil the needs as well, we also need to take care of our act and behaviour while reading the holy Quran. There are several general manners that we, as a reader have to follow.

The first general manner is that we need to have proper attire. Proper attire means that whoever reads the Quran needs to cover all of the aurat. What is aurat? Aurat is the private body parts that as a Muslim, cannot have others who are not the mahram seen it and if they are exposed to the non-mahram, the sins are upon us. As the Quran is a pure reference, even the simplest thing needs to be taken care of, that is why aurat needs to fully-covered before start to recite Quran.

According to the quranreading.com (2014), another etiquette that has to be applied is that the reader needs to be in a clean state or have wudhu' before starting to touch and read the 
Quran. The ablution includes washing hands, mouth, nostrils, arms, a small part of the head and feet to make oneself clean. Cleanliness is super important in Islam as;

Abu Malik at-Ash'ari RA reported, The Messenger of Allah PBUH said: "Cleanliness is half of faith and al-Hamdu Liliah (Praise be to Allah) fills the scale, and SubhanAllah (Glory be to Allah) and al-Hamdu Liliah (Praise be to Allah) fill up what is between the heavens and the earth, and prayer is a light, and charity is proof (of one's faith) and endurance is a brightness and the Holy Quran is a proof on your behalf or against you. All men go out early in the morning and sell themselves, thereby setting themselves free or destroying themselves." (Narrated by Muslim)

Allah SWT said in the Quran

"Indeed, it is a noble Quran. In a Register well-protected; None touch it except the purified." [Quran, 56: 77-79]

This shows that one should be in a clean state which is in ablution in order to touch and recite the Quran.

Another manner that a person needs to keep an eye on is the Quran needs to be placed in a high place whether one is reading it or not. The Quran needs to be put on the pillow or the Quran rack while one is reading it. While one is not reciting it, it also needs to be placed in a high bookshelf to show respect. It is not supposed to be placed on the floor where people walk and cross over the holy Quran because of its high status.

Furthermore, the other etiquette is reciting the Quran with the correct pronunciation and tone. This means that reading the Quran with the tajweed rules is one of the ways for one to apply good manner while reading the Quran. As the language of the Quran is in Arabic and Arabic is known for its complex language, a slight change might affect the meaning of the Quran. That is why reciting Quran needs to be done properly and in the correct ways of reading it.

According from al-Bukhari and Muslim, the Prophet Muhammad PBUH read the Quran with a beautiful voice. Despite the nice voice projection, he also read the holy Quran with the correct pronunciation and tajweed. According to Mohamed (2010), appropriately reading the Quran is crucial and that is why we need to have eligible teachers to teach us the correct way of reciting the Quran.

\section{Conclusion}

The sacred Quran is the most important scripture for humankind, especially to Muslims. A lot of researches have been conducted based on the truth and explanation from the Quran. This holy book also contains a lot of benefits and other important aspects of the world and the hereafter. The Quran brings light and peace to whomever who reads and even only hears it. As a Muslim, one is obliged to believe the Holy Quran without any doubt and always reminds oneself to keep on praying to Allah to get His blessings.

\section{Acknowledgement}

This paper is founded on the research project of the Special Research Grant Scheme UniSZA/2017/SRGS/21 (Project No: R0019-R021). Special appreciation is owed to Ministry of Higher Education Malaysia (MOHE) and Universiti Sultan Zainal Abidin (UniSZA) for sponsoring and supporting this research. 


\section{Corresponding Author}

Wan Khairul Aiman bin Wan Mokhtar (Ph.D), Senior Lecturer.

Universiti Sultan Zainal Abidin (UniSZA), Kampus Gong Badak, 21300 Kuala Nerus.

Email:wk_aiman@yahoo.com/wkhairulaiman@unisza.edu.my

\section{References}

Abdullah, S. (2014). The Contemplative Intelligence In The Quran And Sunnah And Its Role In Knowlledge Acquisition. International Journal of Asian Social Science, 1-15.

Akhtar, S. (2008). The Quran and The Secular Year. Milton Park, Abingdon, Oxon: Routledge.

Alginahi, K. (2014). The Holy Quran Digitization: Challenges and Concerns. Life Science Journal 2013;10(2), 156-164.

Atwell, S. (n.d.). QurAna QurAna: Corpus of the Quran annotated with Pronominal Anaphora. In LREC (pp. 130-137).

Fadhillah. (2016). The Effect Of Reading Qur'an Towards The Emotional Stability Of Grade Xi Students At SMA It Abu Bakar Yogyakarta. E-Journal Bimbingan dan Konseling Edisi 8 Tahun Ke-5, 174-182.

Fadli, S. N. I. A., Mokhtar, W. K. A. W., Amiruddin, E., Rashid, R. A., Idris, M. F. H. M., \& Salleh, A. Z. (2019). Healthy Lifestyle of Prophet Muhammad SAW. International Journal Of Academic Research In Business And Social Sciences, 9(11).

Fauzan. (2015). Pola Pembinaan Baca Tulis Al-Qur'an (Btq) Sebagai Upaya. Ar-Risalah, Vol. XIII No. 1, 19-28.

Hamdan, S. S. B., Mokhtar, W. K. A. W., \& Imas, M. M. (2019). Prayer and Science (Research on the Main Prayer Movement). International Journal Of Academic Research In Business And Social Sciences, 9(11).

Ibrahim, A., Mokhtar, W. K. A. W., Ali, S., \& Simin, M. H. A. (2017). Effect of Transformational Principal Leadership Style on Teachers Commitments and School Achievement. International Journal of Academic Research in Business and Social Sciences, 7(5), 2222-6990.

Julianti, N. D. (n.d.). Dua Syafaat Yang Dinantikan oleh Umat Nabi SAW.

Mohamed, I. A. (n.d.). Al-Quran Awareness: Reality and Challenges in Islamic Education in Schools. Masalah Pendidikan, 241-251.

Mohamed, Y. O. (2010). E-Halagat: An E-Learning System for Teaching The Holy Quran. TOJET: The Turkish Online Journal of Educational Technology, 54-60.

Mokhtar, W. K. A. W. (2017). Concept Al-Hadīth Al-Mawḍū'iy as A Method of Collecting and Analyzing Research's Data. International Journal of Academic Research in Business and Social Sciences, 7(2), 536-542.

Mokhtar, W. K. A. W., Saibi, S. N. S., Abd, N., Ghani, M. M. I., \& Wan, W. M. K. F. (2017). The Concept of Implementation and Application Enthronement of Judges in the Scheme of Memorizing Al-Quran, in the State of Terengganu Malaysia. International Journal of Academic Research in Business and Social Sciences, 7(2), 2222-6990.

Nafi, N. M., Mokhtar, W. K. A. W., \& Mustaffami, M. (2019). The Holy Quran Memorization in Globalization Era. International Journal Of Academic Research In Business And Social Sciences, 9(11).

Quran. (n.d.). Retrieved November 17, 2019, from Oxford Islamic Studies Online: www.oxfordislamicstudies.com/article/opr/t125/e1945

Sooki, S. (2011). Role of Quran recitation in mental health of the elderly. Quarterly of Quran \& Medicine Summer 2011, Volume 1, Issue 1, 17-23. 
Sulaiman. (2014). The Role of Qur'an in the Transformation of Human Society. Revelation and Science, Vol. 04, No. 01 (1435H/2014), 1-13.

Sulaiman. (2014). The Role of Qur'an in the Transformation of Human Society. Revelation and Science Vol. 04, No. 01 (1435H/2014) , 1-13.

The Book of Purification- Sahih Muslim-Sayings and Teachings of Prophet Muhammad . (n.d.). Retrieved November 24, 2019, from Sunnah.com: https://sunnah.com/muslim/2

Tzotzou, M. D. (2014). Designing A Set of Procedures for The Conduct of Peer Observation in the Efl Classroom: A Collaborative Training Model Towards Teacher Development. Multilingual Academic Journal of Education and Social Sciences, 2(2), 16-29. 